\title{
Dinamika Modernisasi Hukum Islam: Tinjauan Historis dalam Pembacaan Mazhab Sociological Jurisprudence
}

\begin{tabular}{llll}
\multicolumn{4}{c}{ Ahmad Zayyadi } \\
Fakultas Syariah IAIN Purwokerto \\
Jl. Jend. A. Yani No. 40-A Purwokerto 53126 \\
Email: ahmedzyd@iainpurwokerto.ac.id
\end{tabular}

\begin{abstract}
Abstrak: Artikel ini mengeksplorasi dinamika modernisasi hukum Islam dengan menggunakan pendekatan sosiologi hukum. Teori hukum yang penulis kaji adalah teori modernisasi hukum Islam sebagai comparative study of Islamic law di dunia Muslim terkait pengaruhnya di Indonesia dengan mengkaitkan pada mazhab sociological jurisprudence yang mempunyai pengaruh besar dalam dinamika modernisasi hukum Islam Modern di dunia termasuk Indonesia. Secara implementatif, mazhab sociological jurisprudence yang diterapkan dalam kajian isu-isu hukum perkawinan masih perlu dilakukan upaya modernisasi, karena persoalan-persoalan tersebut terus berkembang dan posisi hukum harus selalu dinamis dalam menanggapi problem sosiologis. Berbagai pengaruh teoritis dalam sosiologi hukum dan juga sociological jurisprudence mempunyai dampak yang lebih luas pada hukum Islam. Upaya modernisasi hukum Islam ini bagian dari pengembangan teori modernisasi yang mensinergikan secara integratif antara hukum dan masyarakat (law and society) dan masyarakat dan hukum (society and law) secarap proporsional. Artikel ini berusaha mengaplikasikan teori sosiologi hukum pada umumnya dan mazhab socilogycal jurisprudence pada khususnya tentang family law dengan problem sosiologis hukum Islam di masyarakat Muslim semisal Turki, Mesir, dan Indonesia.
\end{abstract}

Kata Kunci: sosiologi hukum, sociological jurisprudence, living law, modernisasi hukum, hukum Islam

Abstract: This article explores the dynamics of the modernization of Islamic law using the sociological approach. The legal theory used is the history of modern law as a comparative Islamic law in the Muslim world related to its influence in Indonesia. The author associates the sociological jurisprudence with the dynamics of modernization of Islamic law in the Muslim world including Indonesia. The sociological jurisprudence is applied in the study of marital law issues that still need efforts to modernize law, because these problems continue to develop and the legal position must always be dynamic in responding to sociological problems that always live in society. Various theoretical influences in the sociology of law and also the sociological jurisprudence have a wider impact on the sociology of Islamic law. This effort to modernize Islamic law is part of the development of modernization theory in the sociology of law, which synergizes integratively between law and society and society and law proportionally. This article seeks to apply the sociology of law in general and the socilogycal jurisprudence in particular about family law with the case of sociological problems of Islamic law in Muslim societies such as Turkey, Egypt, and Indonesia.

Keywords: legal sociology, sociological jurisprudence, living law, modernization of law, Islamic law 


\section{Pendahuluan}

Akar historis perkembangan sosiologi hukum bisa dilihat hasil tulisan para sosiolog dan pakar hukum jauh sebelum berkembangnya sosiologi hukum. Dalam ilmu sosiologi, teori modernisasi menjadi kerangka tersendiri dalam membaca realitas sosial kaitannya dengan ekonomi, politik, dan juga hukum di masyarakat. ${ }^{1}$ Pola relasi antara hukum dan masyarakat, secara sosiologis-antropologis sudah sering dieksplorasi dalam karya-karya Mark Weber dan Emile Durkheim. Karya-karya tentang hukum oleh para sosiolog klasik adalah peletak awal perkembangan sosiologi hukum saat ini, seperti Petrazycki Leon, Eugen Ehrlich, Georges Gurvitch, dan Hans Kelsen, mereka semua adalah penemu teori-teori hukum. ${ }^{2}$

Dalam hal ini, pandangan Weber dapat digambarkan sebagai suatu pendekatan eksternal bagi hukum dengan mempelajari karakteristik empiris hukum. Kemudian, Durkheim berpendapat bahwa sosiologi hukum harus dikembangkan bersama-sama, dan dalam berhubungan dekat dengan, sosiologi moral, mempelajari perkembangan sistem nilai yang tercermin dalam hukum. Berbeda dengan Eugen Ehrlich mengembangkan pendekatan sosiologis terhadap studi hukum dengan fokus kajiannya pada bagaimana kehidupan sosial, jaringan sosial, dengan membedakan antara "positivelaw" yang terdiri dari norma-norma kompulsif membutuhkan pejabat negara bagian penegakan hukum, dengan "living law" yang terdiri dari aturan-aturan perilaku yang benar-benar orang mematuhi dan mendominasi kehidupan sosial. ${ }^{3}$

Begitu juga dengan Theodor Geiger, ia mengembangkan analisis teori hukum Marxis dengan menyoroti bagaimana hukum menjadi "faktor transformasi sosial dalam masyarakat demokratis dari jenis yang diatur oleh ungkapkan persetujuan hak pilih universal dari populasi yang dilakukan secara teratur". Begitu juga dengan Georges Gurvitch yang juga berbeda dengan Gieger, ia suka mengkaji fusi manifestasi simultan hukum dalam berbagai bentuk dan berbagai tingkat interaksi sosial. Ia berusaha merancang konsep hukum sosial sebagai hukum yang integrative, sehingga Gurvitch dikenal sebagai salah satu kontributor bagi penemuan teori pluralisme hukum.

Dari tahun ke tahun, berbagai teori telah muncul dalam sosiologi hukum karena para pakar hukum selalu mengembangan dengan teori-teori sosial yang ada. Di antara pengaruh-pengaruh baru-baru ini dapat disebutkan karya filsuf Perancis Michel Foucault dan Jerman Jürgen Habermas tentang teori feminisme, postmodernisme, dekonstruksi, neo-Marxisme, dan behaviorisme. Berbagai pengaruh teoritis dalam sosiologi hukum juga ditandai hak yang lebih luas dan ruang lingkup perusahaan. Pada bidang multidisiplin hukum dan masyarakat (law and society) tetap sangat populer, sedangkan disiplin khusus sosiologi hukum adalah lebih terorganisir dari sebelumnya di tingkat institusional dan professional yang berlaku bagi masyarakat.

\section{Pendekatan Sosiologi dalam Studi Ilmu Hukum Modern}

Sosiologi hukum ditetapkan sebagai bidang studi akademis dan penelitian empiris setelah Perang Dunia Kedua. Studi hukum sendiri bukan merupakan sentral dalam sosiologi, meskipun

Zdenek Suda, Teori, Riset, Dan Realitas, ed. Hartono Hadikusumo (Yogyakarta: Tiara Wacana, 1998), 63.

B. Arief Sidarta, Filsafat Hukum Mazhab Dan Refleksinya (Bandung: Remaja Rosda Karya, 1994), 40.

Sidarta. 
beberapa sosiolog terkenal sudah menulis tentang peran hukum dalam masyarakat. Talcott Parsons misalnya, ia mengatakan bahwa hukum dipahami sebagai suatu mekanisme penting dari kontrol sosial. Philip Selznick, juga berpendapat bahwa hukum modern menjadi semakin responsif terhadap kebutuhan masyarakat dan bahkan sangat dekat dengan moral, namun Donald Black (sosiolog Amerika), mengembangkan teori ilmiah dari biro hukum dasar sebuah paradigma sosiologi murni. Niklas Luhmann Jerman melihat hukum sebagai normatif yang tertutup tetapi membuka sistem kognitif atau menenerapkan sistem kontemporer. Artinya, semua kehidupan manusia kolektif secara langsung atau tidak langsung ditetapkan oleh hukum. Hukum adalah seperti pengetahuan, sebuah fakta penting, dan semua-meresap kondisi sosial tentunya.

Selain tahun-tahun terakhir, berbagai teori telah muncul dalam sosiologi hukum karena proliferasi teori dalam sosiologi pada umumnya. Di antara pengaruh-pengaruh baru-baru ini dapat disebutkan karya filsuf Perancis Michel Foucault, Jerman Jürgen Habermas. Berbagai pengaruh teoritis dalam sosiologi hukum seperti teori feminisme, postmodernisme, teori dekonstruksi, neoMarxisme, dan behaviorisme, juga merupakan perkembangan bidang multidisiplin hukum dan masyarakat tetap sangat popular.

Perbedaan utama antara sosiologi hukum dan Hukum dan Masyarakat adalah tidak membatasi diri secara teoritis atau metodologis untuk sosiologi dan bukannya mencoba untuk mengakomodasi wawasan dari semua disiplin ilmu-ilmu sosial termasuk antropologi dan bahkan psikologi. Selama tahun 1970-1980-an sejumlah studi empiris asli yang dilakukan oleh sarjana Hukum dan Masyarakat tentang resolusi konflik. William Felstiner misalnya, mempunyai cara-cara menyelesaikan konflik (menghindari, mediasi, litigasi, dll) yang terjadi di tengah-tengah masyarakat konflik. Selain itu, Richard Abel, Austin Sarat, dan Felstiner mengembangkan ide sebuah piramida perselisihan dan rumus seperti penamaan, menyalahkan, dan mengklaim yang mengacu pada berbagai tahap resolusi konflik dan tingkat piramida sebagai solusi di masyarakat.

Terdapat beberapa hal penting dalam studi interdisipner dalam studi sosiologi hukum seperti sociological jurisprudence yang berusaha mendasarkan argumen pada wawasan hukum dan sosiologis, bukan sebagai teori hukum, yang terkait dengan praktek yang biasa adalah untuk menciptakan lembaga-lembaga hukum dan operasi sosial yang mereproduksi sistem hukum dari waktu ke waktu. (berkembang di Amerikan dan Eropa oleh Pound Roscoe, Eugen Ehrlich, dan Georges Gurvitch). Sebagaiman kita ketahui, masyaratakat (manusia) tidak akan bisa hidup tanpa ada hukum yang mengatur kehidupan tentang mereka. Hukum dan masyarakat tetap selalu berubah sesuai perkembangan zaman dari zaman primitif, hingga modern. Munculnya istilah modernisasi hukum juga ada kaitannya dengan berbagai macam teori hukum yang masuk dalam ranah hukum Islam. Teori-teori hukum juga banyak yang diserap oleh hukum Islam, seperti teori Ustin (Autinian theory), "materi Ilmu Hukum" kata Austin, "adalah hukum positif secara sederhana dan singkat disebut sebagai hukum saja, atau hukum yang ditetapkan oleh para politisi yang berkuasa terhadap rakyat yang mereka kuasai". ${ }^{4}$ Menurut tokoh lain seperti Hans Kelsen disebut sebagai teori hukum murni (pure theory of law) atau juga bisa disebut sebagai aliran atau mazhab hukum impreatif (imperative school). ${ }^{5}$

Dari berbagai macam aliran hukum yang berkembang di dunia Islam Modern, yaitu dikenal

${ }^{4}$ J. N. D. Anderson, Hukum Islam Di Dunia Modern (Surabaya: Amar Press, 1991), 5.

Anderson, 6. 
dengan mazhab hukum sosiologik dalam Ilmu Hukum. Menurut para ahli hukum dari mazhab atau aliran ini, perhatian tidak terlalu ditujukan pada sejarha hukum sebagai pengaruh timbal balik antara hukum dan masyarakat. Menurut Anderson barangkali merupakan gambaran mengagumkan tentang hukum Islam yang mengalami perkembangan sepanjang sejarahnya; walaupun secara radikan ia tidak mempengaruhi teori-teori hukumnya. Menurut teori ini bahwa bukan masyarakat yang mempengaruhi hukum, melainkan hukum yang menyajikan norma dan pedoman berdasarkan wahyu Tuhan (devine law) dan umat Islam terikat untuk melaksanakannya. ${ }^{6}$

Sebagai bentuk konkrit sumbangsih kelimuan penulis memadukan antara teori sosiologi hukum yang juga berbeda dengan socialogical jurispridence yang merupakan sebuah mazhab filsafat hukum yang berolak belakang dengan sosiologi hukum. Dalam arti lain, socialogical jurispridence mempunyai ciri khas, yaitu hubungan timbal balik antara law and society dengan bentuk memberikan pengaruh hukum kepada masyarakat. Berbeda dengan sosiologi hukum lebih pada sisi masyarakat yang mempengaruhi hukum (society and law).

\section{Perkembangan Modernisasi Hukum di Dunia Muslim}

Dalam pendekatan histroris sociological jursiprudence adalah studi empirik realitas hukum yang benar-benar menjadi sebuah kenyataan sosioal (social reality) yang berkembang dan hidup di masyarakat (field of social experience and living law). Teori dan pengkajian realitas hukum dan masyarakat (law and society) ini disebut dengan istilah sociological jurisprudence atau sosiologi hukum yang dalam hal ini secara empiris dapat menjadi kajian teoritis terkait dengan proses negoisasi (negotiating process) berbagai model interaksi antara hukum, beberapa kelembagaan hukum, dan lembaga-lembaga hukum lainnya terkait dengan gejala sosial dan perubahannya yang terus berjalan hidup di masyarakat (living law). Terkait dengan modernisai hukum di dunia Islam Modern terdapat tulisan dalam tulisan Sami Zubaida dan J.N.D. Anderson, sebagai penunjang dari pembahasan ini, karena Sami Zubaidah sendiri merujuk pada karya Anderson ini. ${ }^{7}$ Menurut hemat penulis bahwa dinamika modernisasi hukum bersamaan dengan dinamika modernisasi hukum yang terjadi di Turki yang mempunyai pengaruh besar terhadap modernisasi hukum Islam di dunia Muslim termasuk Indonesia.

Modernisasi hukum menurut Sami Zubaidah adalah untuk membuat hukum menjadi hukum negara yang dikodifikasi secara standard, dengan cara mencangkok terhadap apa yang sudah menjadi otoritas hukum yang tidak menggunakan hukum agama (devine law), sekaligus menghindari dari karakterisik hukum Islam yang bersifat pluralistik, debatable, bersifat plural yang memang pada kenyataannya, hukum Islam lahir dari segi tradisi historisnya sejak zaman kenabian hingga era moden sudah berkarakter. ${ }^{8}$ Dinamika modernisasi hukum di berbagai negara Muslim yang sangat plural dan debatable di kalangan modernis-progresif dan tradisionalis-konservatif ini memang sebuah fakta empiris yang tidak bisa dibendung khususnya pergulatan hukum yang terjadi di Turki, Libya, Lobanon, Mesir menjadi pelopor terjadinya social movement, sehingga kalau mau berbicara reformasi hukum harus berkiblat kajiannya pada negara-negara Muslim progresif termasuk Indonesia yang juga sangat getol memperjuangan reformasi hukum.

\footnotetext{
Anderson, 7.

J. N. D. Anderson, Law Reform in the Muslim Word (London: Athlon Press, 1976).

8 Sami Zubaida, Law and Power in The Islamic World (London: MPG Book, 2003), 121-2.
} 
Dalam perkembangannya, negara-negara Muslim sangat mempunyai daya tawar yang strategis. Dalam perspektif pemikiran Tahir Mahmood membagi tiga hal posisioning penting terkait negaranegara Muslim dalam memperlakukan hukum Islam. Pertama, hukum Islam yang dianut adalah negara yang menerapkan hukum keluarga Islam tradisional yakni, Yaman, Kuwait, Arab Saudi, Afganistan, Somalia, dan negara-negara lainnya yang cenderung radikal dalam menerapkan hukum Islam konfensional (konserfatif). Kedua, Negara-negara Muslim yang tidak sungkan-sungkan dan berani menerapkan hukum sekuler seperti Turki, Mesir, Tanzania, Albania, Philiphina, dan Uni Sovyet. Ketiga, adalah negara-negara yang mengaplikasikan hukum Islam dengan memadukan kedua model negara yang tersebut di atasa, yaitu negara yang melakukan modernisasi secara substantif dan pembaharuan perundang-undangan yang hidup di Masyarakat (sociological jurisprudence) dengan mempertimbangkan nila-nilai folosifis dengan tanpa harus menjadi sekuler atau konserfatif'seperti di Indonesia yang bukan negara Islam dan bukan negara sekuler. Istilah lain dari modernisasi hukum adalah reformasi hukum (law reform) dan atau istilah lain pembaharuan, dalam istilah tradisi Islam adalah tajdid. Sejarah reformasi pertama kali di dunia Muslim itu adalah Turki yang kemuidan diikuti oleh Lebanon, kemudia diikuti oleh Mesir, Brunei, Malaysia dan hingga ke Indonesia juga masuk kategori ini.

Dalam hal ini, Turki sangat mempunyai peranan penting dan strategis dalam sejarah hukum yang ada di Asia Barat. Reformasi Hukum perdata di Turki awal mulanya hanya menganut mazhab Imam Abu Hanifah, meskipun juga memberi kelenturan untuk mengikuti mazhab yang lainnya. Fakta empiris yang dilakukan Turki adalah lahirnya Majallāt al-Ahkām al-Adliyah pada tahun 1876 merupakan persiapannya, tetapi belum mengakomudir hukum keluarga (family law). akhirnya pada tahun 1915 dirintislah aturan perundang-undangan tentang perkawinan dan perceraian. Para era ini, materi perubahannya adalah terkait dengan kewenangan (hak) menuntut cerai adalah hanya menjadi otoritas suami, dari cikal bakal inilah kemudian terjadi gejolak dan gerakan sosial, akhirnya masyarakat Turki mendesak pemerintahnya untuk segera melakukan reformasi hukum (law reform). ${ }^{10}$

Sosiologi hukum (sociology of law) dan sociological jurisprudence ini mengkaji, menganalisis, menemukan sebuah objek penelitian dengan cara membahas pengaruh timbal balik antara perubahan hukum dan masyarakat, atau sebaliknya yang dapat menjadikan perubahan hukum yang terjadi di masyarakat. ${ }^{11}$ Perubahan sebuah hukum itu tidak bisa lepas dari adanya sebuah gejolak, dinamika, dan tantangan dalam sebuah langkah reformasi hukum (law reform). Dari sisi sociological jurisprudence pada hakikatnya hampir sama dengan sosilologi hukum, akan tetapi yang paling penting dalam madzhab sociological jurisprudence ini terdapat komunkasi timbal balik antara hukum Islam dengan dan masyarakat Muslim (muslem society) dalam hal ini Turki, Mesir, dan dunia Muslim laninnya, sehingga dapat terjadi neosiating process secara dinamis antara masyarakat dan hukum secara bersalin keindahan, seimbang secara dinamis dan estetis sesuai kebutuhan masyarakat. ${ }^{12}$

Salah satu contoh bahwa mazhab sociological jurisprudence ini mempunyai pengaruh besar, dapat kita lihat pendapat N.J. Coulson bahwa seorang sarjana Barat membuat komentar The Ottoman Law of Family Right merupakan prinsip yang sangat urgen dalam upaya-upaya modernisasi undang-undang

\footnotetext{
Tahir Mahmood, Family Law Reform in the Muslim World (New Delhi: Pvt. Ltd, 1972).

10 Anderson, Hukum Islam Di Dunia Modern, 57-8.

11 Sudirman Tebba, Sosiologi Hukum Islam (Yogyakarta: UII Press, 2003), 131.

12 Tebba, ix.
} 
hukum keluarga. ${ }^{13}$ Sebagaimana yang ditulis Tahir Mahmood, Undang-undang Sivil yang didasarkan pada mazhab Hanafi sudah dipersiapkan pada 1876 di Turki, hukum perdata Turki juga bedasarkan pada mazhab Hanafi, namun kemudian juga menampung mazhab-mazhab lain, seperti dalam Majallāt al-Ahkām al-'Adliya yang telah dipersiapkan sejak tahun $1876 .{ }^{14}$ Modernisasi hukum modern juga merupakan cabang daeri sosiologi hukum dan juga mazhab sociological jurisprudence ini, Joseph Schacht dalam The Law, Unity and Variety in Moslem Civilization juga mengamati tentang modernisasi hukum di dunia Islam Modern dengan mengatakan bahwa:

Metode yang digunakan oleh para modernis yang membuat undang-undang adalah menikmati eklektisisme bebas, penalaran bebas, yang mereka tuntut jauh melebihi yang dijadikan pada periode perkembangan hukum Islam; pendapat yang pada waktu tertentu dipegang mungkin dikeluarkan dari konteksnya dan digunakan sebagaimana mestinya. Di satu sisi, para modernis permbuat undang-undang cenderung menolak karakter agama (devine law) dari bab-bab pokok hukum yang suci. Di sisi lain, mereka cenderung menggunakan interpretasi yang sewenangwenang (despotism) dan dipaksakan atas Al-Qur'an dan Hadis di mana saja sesuai kebutuhan mereka. Secara material, mereka adalah pembaru yang berani menginginkan modernisasi betapaun mahal. Secara formal mereka mencoba menghindari kemiripan (bentuk) yang melibatkan kandungan pokok hukum suci. Teori-teori dan argmentasi-argumentasi mereka datang dari Barat, tetapi mereka tidak ingin menolak hukum yang suci secara terang-terangan seperti yang dilakukan oleh Turki. ${ }^{15}$

Gerakan modernisme hukum di dunia Islam seperti yang dipelopori oleh Jamaluddin al-Afghani, Muhammad Abduh di Mesir juga merupakan pengaruh dari sekularisme Barat, ilmu, ekonomi, hukum, dan literaturnya ${ }^{16}$ Reformasi hukum Islam di Turki merupakan tonggak sejarah modernisasi hukum Islam di dunia Muslim dan mempunyai pengaruh yang besar terhadap perkembangan hukum Islam (family law) di negara-negara lain. Dengan hadirnya orang-orang Turki di Eropa seperti Perancis, Inggris, Belanda, dan Jerman pengkajian terhadap studi hukum Islam (Islamic law studies) mulai diperkenalkan bahkan kontak Turki dengan negara-negara Muslim di Asia dan Afrika. ${ }^{17}$

Selain di Turki, negara-negara Islam yang dijahah oleh Barat khsususnya Eropa, kehidupan orang Barat masuk ke dunia Arab mempengaruhi cara hidup dan budaya tradisi masyarakat orangorang Islam. Salah satu contoh perempuan mulai diberi kebebasan dalam kegiatan masyarakat seperti bekerja, belajar, dan seterusnya. Hal ini menunjukkan mulai ada integrasi dan negosiasi antara law in book dan law in action antara hukum dan masyarakat, meskipun sampai saat ini, termasuk Indonesia masih belum siap menerima isu-isu modernisasi hukum yang muncul di dunia Islam, karena oleh sebagian kalangan dianggap ada intervensi politik hukum dari Barat.

Turki, merupakan tonggak sejarah munculnya modernsasi hukum Islam (family law), setelah itu Mesir menjadi pemeran utama reformasi hukum di dunia Muslim. Usaha modernisasi khususnya dalam bidang hukum keluarga dilakukan pertama kali oleh Muhammad Qadri Pasya pada 1893 dengan membentuk kodifikasi peraturan perundang-undangan yang menjadi rujukan penting bagi para hakim sekuler di Mahkamah Sekular (Mahākim Mukhtalițah) dan cendikiawan Mesir. Kodifikasi tersebut diberi nama Al-Aḥkām al-Syari’ah al-Ahwal al-Syakhșiyah (hukum syari'ah di dalam

\footnotetext{
13 Ahmad Hidayat Buang, "Reformasi Undang-Undang Keluarga Islam," Syari'ah 5, no. 1 (1997).

14 Khoiruddin Nasution, Hukum Perdata (Keluarga) Islam Indonesia: Dan Perbandingan Hukum Perkawinan Di Dunia Muslim (Yogyakarta: Tazzafa \& Academia, 2009), 166.

15 Schacht, The Law, Yunity and Variety in Moslem Civilization (Chicago: University of Chicago Press, 1955), 65.

16 H. A. R. Gibb, Modern Trends In Islam (Chicago: Chicago University Press, 1994), 34.

17 Anderson, Hukum Islam Di Dunia Modern, xxiv.
} 
soal-soal hukum perorangan) yang berasaskan madzhab Hanafi. ${ }^{18}$ Kodifikasi di Turki juga dikenal dengan Qānūn Ḥuqūq al-'Á'ilah al-Uśmāniyyah (Undang-undang Hak-hak Keluarga Usmaniyyah) yang ditawarkan oleh Sultan Turki dan Undang-undang tersebut bermadzhab Maliki. ${ }^{19}$ Dalam hal ini, Turki merupakan pencetus utama dalam sejarah reformasi Hukum Islam, khususnya dalam bidang hukum perdata (keluarga) Islam yang dilakukan pada 1917 yang dikenal dengan The Ottoman Law of Family Rights (Qānūn al-Qarār al-Huqūq al-Ā'ilah al-Uśmāniyyah), ${ }^{20}$ sehingga hukum keluarga mempunyai posisi yang penting dalam sejarah hukum Islam di dunia Muslim.

Salah satu potret perkembangan modernisasi hukum keluarga di Turki yang megalami beberapa kali amandemen adalah aturan-aturan hukum tentang perceraian dalam perundang-undangan telah mengalami perkembangan yang cukup pesat jika dibandingkan dengan figh konvensional. Perkembangan reformasi ini mulai memberikan harapan kepada perempuan Muslim yang selama ini hukum Islam dianggap bias dan merugikan kaum perempuan. ${ }^{21}$ Seperti halnya di Mesir, kaum laki-laki banyak melakukan poligami dengan perempuan dan kemudia dicerai dengan tanpa alasan. Fenomena inilah yang kemudian Muhammad Abduh dan Qasim Beek Amin melakukan reformasi pemikirannya melalui dua buku masterpeace-nya, Tahrir al-Mar'ah dan al-Mar'ah al-Jadidah, sehinggsa kedua kitab hasil riset Muhammad Abduh dan Qasim Amin ini, Mesir melahirkan produk Undangundang hukum keluarga Islam yang berkembang di era hukum Modern. Upaya modernisasi Hukum Keluarga yang dilakukan di Turki pada tahun 1917 dan dengan lahirlah UU Civil Turki tahun 1926 (The Turkish Civil Code 1926), ${ }^{22}$ begitu juga dengan Republik Arab Mesir dimulai pada tahun 1920 dengan lahirnya Undang-Undang Keluarga Mesir, yaitu Law No. 25 tahun 1920 dan Law No. 20 tahun 1929. Akan tetapi, sebelum diresmikan Undang-undang tersebut, misalkan tentang usulan pembatasan poligami dan hak cerai sepihak oleh suami selalu gagal di Republik Arab Mesir. Seperti pada dalam draf UU No. 25 Tahun 1920 ditolak keras oleh ulama Mesir. ${ }^{23}$

Setelah mengalami penolakan oleh ulama Mesir, kemudian draf tersebut diusulkan kembali oleh komite Mesir tahun 1927 untuk UU No. 20 Tahun 1929 yang isinya hampir sama dengan draf yang ada dalam UU No. 25 Tahun 1920, tetapi UU No. 20 Tahun 1929 merupakan pengaruh dari pemikiran Muhammad Abduh dan Qasim Amin penulis buku Tahrïr al-Mar'ah (Pembebasan Perempuan) di Mesir. Aturan tersebut masih gagal karena waktu itu diveto oleh Raja Fu'ad. Kemudian pada Tahun 1943 dan 1945 diusulkan lagi, tetapi juga ditolak oleh kerajaan Mesir. ${ }^{24}$ Akan tetapi, sebelum terbentuknya UU (Amandemen Law) No. 100 Tahun 1985, Mesir sudah mempunyai UU Hukum Keluarga yaitu UU No. 25 tahun 1920 tentang Nafkah dan Perceraian, selain itu UU No. 56 tahun 1923 tentang Umur Perkawinan, UU No. 25 tahun 1929 tentang Perceraian, UU No. 77 tahun 1943 tentang Waris, dan UU No. 71 tahun 1946 tentang Wasiat, dan seterusnya. Dengan demikian maka Mesir adalah negara kedua setelah Turki dan negara pertama di Arab yang mengadakan pembaharuan Hukum Keluarga. Isi pokok dari UU No. 56 tahun 1923 dan UU No. 25 tahun 1920 terfokus kepada bidang perceraian.

\footnotetext{
18 Buang, "Reformasi Undang-Undang Keluarga Islam."

19 Buang.

20 Khoiruddin Nasution, Hukum Perdata (Keluarga) Islam Indonesia: Dan Perbandingan Hukum Perkawinan Di Dunia Muslim (Yogyakarta: Tazzafa \& Academia, 2009), 166.

${ }^{21}$ Khoiruddin Nasution, Status Wanita Di Asia Tenggara: Studi Tentang Perundangundangan Perkawinan Muslim Kontemporer Di Indonesia Dan Malaysia (Jakarta: INIS Press, 2002), 284-5.

22 Nasution, Hukum Perdata (Keluarga) Islam Indonesia: Dan Perbandingan Hukum Perkawinan Di Dunia Muslim, 284-285.

23 Nasution, Status Wanita Di Asia Tenggara: Studi Tentang Perundangundangan Perkawinan Muslim Kontemporer Di Indonesia Dan Malaysia.

24 Nasution, 286.
} 
Kedua UU ini kemudian diperbaharui pada tahun 1979 dengan lahirnya UU yang dikenal dengan Hukum Jihan Sadat No. 44 tahun 1979. UU ini pun diperbaharui lagi dengan bentuk Personal Status (Amandemen Law) No. 100 tahun 1985..$^{25}$

Dalam penelitian mengenai dinamika modernisasi hukum Islam di dunia Islam, J. N. D Anderson dan John L. Esposito yang mengatakan bahwa metode yang umumnya dikembangkan dalam modernisasi hukum menangani isu-isu hukum masih bertumpu pada pendekatan yang adhoc dan terpilah-pilah dengan menggunakan prinsip takhayyur dengan mengembangkan metode yurisprudensi yang karena dalam situasi spesifik dibolehkan meninggalkan madzab hukumnya untuk mengikuti madzab lain dan juga talfí yaitu mengkombinasikan berbagai madzhab untuk membentuk peraturan tunggal. ${ }^{26}$

\section{Impelementasi Mazhab Sociological Jurisprudence terhadap Modernisasi Hukum Islam Indonesia}

Berbicara soal teori modernisasi hukum dalam ilmu sosiologi hukum, sangat penting untuk membedakan tipologi hukum modern dan hukum konservatif. Artinya, adanya modernisasi hukum karena adanya tradisi hukum konservatif atau disebut tradisional. Menurut Muhammad Amin Summa dalam bukunya Hukum keluarga Islam di Dunia Islam bahwa semua Negara-negara Islam dan Negaranegara berpenduduk Muslim (baik minuritas maupum mayoritas berlaku hukum keluaga Islam di lingkungan keluarga Muslim. Dikenal dengan dua ciri yaitu uncodifide law (hukum tidak terkodifikasi atau tidak tercatat) dan codified law (hukum yang tercatat). ${ }^{27}$

Hukum yang tidak tertulis (uncodifide law) umumnya umumnya Negara-negara Muslim minoritas seperti Burma, Philipina, Thailand, dan lain-lain. hukum yang tercatat (codified law) seperti Turki yang dikenal dengan Fifty Years of Personal Law Refom 1915-1965 (Turki: 50 Tahun Pembaruan Hukum tentang Pribadi 1916-1965, Sudan: Reform and Protection of Personal Law 1916-1986, Lebanon; The law on Family Rights 19170-1962, Pakistan: Reforn and Protection of Personal Law 1947-1987, Syria: The Code of Personal Status 1953 as Amandemen ded in 1975, Indonesia The Law on Marriage 1974 atau peraturan Pemerintah No. 9 Tahun 1975 dan Instuksi Presiden No. 1 Tahun 1991 tentang Kompilasi Hukum Islam (KHI), dan seterunya masih banyak Negara-negara Muslim mayoritas yang mempunyai undangundang hukum tertulis. ${ }^{28}$

Dari sinilah muncul penilian bahwa hukum tertulis (codified law) menjadi tanda dan ciri dari hukum modern yang harus mengatur serta melayani kehiduan modern. Pembaruan hukum modern atau disebut modernisasi hukum mulai terjadi pada Abad ke-19, namun hukum keluarga Islam pada kebanyakan Negara-negara Islam tetap tidak mengalami perubahan yang berarti. Pada abad ke-19, modernisasi hukum keluarga dapat dilihat dengan upaya penggantian hukum Islam dengan hukum Barat, tetapi juga oleh perubahan-perubahan hukum Islam itu sendiri di sana sini yang didasarkan atas penasfsiran kembali terhadap tradisi hukum Islam sesuai dengan penalaran dan pengamalannya. ${ }^{29}$

Menurut Munir Fu'ady terdapat dua tipologi masyaratakat yaitu masyaratak tradisional (kuno)

\footnotetext{
25 Nasution, 94.

26 J. N. D. Anderson, Law Reform in the Muslim Word (London: Athlon Press, 1976), 42.

27 Muhammad Amin Summa, Hukum Keluarga Islam Di Dunia Islam (Jakarta: RajaGrasindo, 2004), 165.

28 Summa.

29 Satjipto Rahardjo, Ilmu Hukum (Bandung: Citra Adtya Bakti, 1991), 72.
} 
dan masyarakat modern. Kaitannya dengan teori sociological jurisprudence dalam perkembangan teori hukum dalam masyarakat, bahwa masyarakat modern, hukum harus modern pula dan harus terdapat interaksi antara hukum dan perkembangan masyarakat. Sebagaimana yang dingkapkan Roscoe Pound, hukum berfungsi sebagai tools of social engineering..$^{30}$ Menurut Marc Galenter sebagaimana yang dikuti Munir Fu'ady bahwa cirri-ciri hukum yang maju/modern adalah sebagai berikut:

1. Terdapat aturan yang seragam, baik substansinya, maupun pelaksanannya;

2. Hukum bersifat traksaksial yang berarti bahwa hak dan kewajiban timbul dari perjanjian tanpa dipengaruhi oleh usia, kelas, agama, gender, ras, dan lain-lain;

3. Hukum bersifat universal yang berarti hukum dapat diterima oleh umum (masyarakat);

4. Hierarkis peradilan yang tegas;

5. Bersifat birokratis, artinya prosedur dilaksanakan sesuai yang telah ditetapkan oleh undang-undang;

6. Hukum menjadi lebih rasional;

7. Pelaksana hukum lebih professional (tidak debatable);

8. Karena menjurus kepada spesialisasi, harus ada jembatan penghubung antara satu spesialisasi dengan spesialisasi yang lain;

9. Fleksibel, yakni mudah diubah untuk disesuaikan dengan perkembangan masyarakat;

10. Hukum dilaksanakan oleh Negara atau lembaga-lembaga Negara;

11. Berlaku prinsip trias politika. ${ }^{31}$

Beberapa tipologi masyarakat hukum Modern di atas masih banyak lahir beberapa teori modernisasi hukum yang dalam hal ini teori sociological jurisprudence dengan berorientasi pada tatanan-tatanan hukum maju atau mapan dan matang mempunyai kesamaan bahwa mereka tatanan-tatanan dunia sekuler, yang di dalammnya penyelenggaraan hukum berlandaskan jalan pikiran rasional dan mempunyai kepastian hukum di masyarakat. ${ }^{32}$ Kembali ke masalah orientasi dari hukum kuno ke hukum modern, sebagaimana yang dikatakan Fu'ady bahwa arah pergerakan evolusi hukum kuno menjadi hukum modern dengan beberapa cirri sebagai berikut:

1. Menuju ke hukum yang lebih rasional;

2. Menuju ke hukum yang lebih melindungi hak-hak dasar manusia;

3. Menuju ke hukum yang lebih berorientasi ke teknologi ke industrialisasi;

4. Menuju ke hukum yang lebih universalistik;

5. Menuju ke hukum yang lebih profesional;

6. Menuju ke hukum yang lebih prediktif;

7. Menuju ke hukum yang lebih legalistik;

8. Menuju ke hukum yang evolutif dan adaptif;

9. Menuju ke hukum yang lebih terukur (kuantitatif), jelas, dan pasti;

10. Menuju ke hukum yang transaksional dan kontraktual;

11. Menuju ke hukum yang restruktur, hierarkis, dan politis. ${ }^{33}$

\footnotetext{
30 Munir Fuady, Teori-Teori Dalam Sosiologi Hukum (Jakarta: Predana Media Group, 2011), 109.

${ }^{31}$ Salam \& Anton F. Susanto Otje, Beberapa Aspek Sosiologi Hukum (Bandung: Alumni Press, 2004), 110-1.

32 Emiritus John \& Emiritus Frits Gorle Gilissen, Sejarah Hukum Suatu Pengantar, ed. Fredi Tengker (Jakarta: Refika Aditama, 2009), 66.

33 Fuady, Teori-Teori Dalam Sosiologi Hukum, 105.
} 
Dalam perkembangan teori modernisasi hukum, juga sangat identik dengan teori sociological jurisprudence yang dibangun oleh Roscoe Pound bahwa hukum berfungsi sebagai a tool of social engineering artinya hukum bersifat statis dan konservatif, sedangkan masyarakat cenderung dinamis, sehingga ada kecenderungan tarik menarik antara hukum (salah satu subsistem dalam masyarakat) dan perkembangan masyarakat sebagai sistemnya. ${ }^{34}$ Oleh karena itu, mazhab sociological jurisprudence juga mempunyai pengaruh besar terhadap perkembangan hukum keluarga Islam, termasuk di Indonesia yang penduduknya mayoritas Muslim.

Termasuk salah satu tipologi hukum modern menurut Muhammad Amin Summa terdapat dua hal untuk membedakan antara hukum tradisonal dengan modern yaitu hukum tradisional dikenal dengan hukum yang tidak tertulis (uncodifide law) umumnya Negara-negara Muslim minoritas seperti Burma, Philipina, Thailand, dan lain-lain. Sedangkan hukum modern yaitu hukum yang tercatat (codified law) seperti Turki yang dikenal dengan Fifty Years of Personal Law Refom 1915-1965 (Turki: 50 Tahun Pembaruan Hukum tentang Pribadi 1916-1965, Sudan: Reform and Protection of Personal Law 1916-1986, Lebanon; The law on Family Rights 19170-1962, Pakistan: Reforn and Protection of Personal Law 1947-1987, Syria: The Code of Personal Status 1953 as Amandemen ded in 1975, Indonesia The Law on Marriage 1974 atau peraturan Pemerintah No. 9 Tahun 1975 dan Instuksi Presiden No. 1 Tahun 1991 tentang Kompilasi Hukum Islam (KHI), dan seterunya masih banyak Negara-negara Muslim mayoritas yang mempunyai undang-undang hukum tertulis.

Selain teori modernisasi hukum, konsep mazhab sociological jurisprudence juga mempunyai kontribusi tersendiri, terutama hubungannya dengan perkembangan hukum di Indonesia. Pemikiranpemikiran hukum modern yang dianggap dapat memenuhi tuntutan-tuntutan modern sekarang ini tumbuh di Eropa yang lebih menekankan pada fungsi dan peranan hukum dalam masyarakat.

Madzhab sociological jurisprudence yang dikemukakan oleh Eugen Ehrlich dalam Grundlegung der Sociological rechts 1913 dinyatakan bahwa masyarakat adalah ide umum yang dapat digunakan untuk menandakan semua hubungan sosial, seperti keluarga, desa, lembaga lembaga sosial, negara, bangsa, sistem ekonomi, sistem hukum, dan lain sebagainya. Ehrlich memandang bahwa semua hukum adalah hukum sosial yang selalu dapat dibentuk dan proses legal draft suatu peraturan perundangundangan dapat dinegosiasikan dengan masyarakat. ${ }^{35}$ Termasuk norma-norma hukum berasal dari kenyataan dalam masyarakat atau hukum yang baik ada sesuai dengan kehidupan yang hidup di masyarakat (living law atau living figh). ${ }^{36}$

Berbicara masalah hukum, dapat mudah ditaati dan berjalan apabila sesuai dengan aspirasi masyarakat, atau hukum dapat berlaku efektif, yaitu ketika mucul dari aspirasi masyarakat dan kemudian direspons oleh legislatif dan eksekutif. ${ }^{37}$ Menurut Soerjono Soekanto, efektivitas berlakunya hukum ditentukan oleh tiga aspek, yaitu aspek yuridis (pembentukannya sesuai prosedur), aspek sosiologis (sesuai dengan kondisi sosial masyarakat) dan aspek filosofis (sesuai dengan cita-cita hukum). Termasuk struktur hukum (institusi penegakan hukum), substansi hukum (norma hukum), dan budaya hukum (sikap masyarakat terhadap hukum). ${ }^{38}$ Dari sinilah sebenarnya perkembangan

\footnotetext{
34 Fuady, 37.

35 Sobhi Mahmassani, Filsafat Hukum Dalam Islam, ed. Ahmad Sudjono (Bandung: PT. Maarif, 1981), 213.

36 Rasjidi dan Ira Rasjidi, Dasar-Dasar Filsafat Dan Teori Hukum (Bandung: PT.Citra Aditya Bakti, 2001), 66.

37 A. Malthuf Siroj, Pembaruan Hukum Islam Di Indonesia Telaah Kompilasi Hukum Islam, ed. Muhammad Al-Fayyadl (Yogyakarta: Pustaka Ilmu, 2012), 34-5.

38 Soerjono Soekanto \& Purnadi Purbacaraka, Perihal Kaidah Hukum (Bandung: Citra Aditya Bakti, 1989), 88.
} 
modernisasi hukum atau menuju hukum modern dapat dilihat dan di analisis melalui beberapa faktor di atas.

Di Indonesia, hukum Islam pernah dan dilaksanakan dengan sepenuhnya oleh masyarakat Islam. Meski didominasi oleh figh Syafi'i. Model figh ini lebih banyak dan dekat dengan kepribadian Indonesia. Hukum adat setempat sering menyesuaikan diri dengan hukum Islam. Hukum waris hukum Islam dan hukum adat, keduannya menyatu dan hukum adat itu menyesuaikan diri dengan hukum Islam. Sosialisasi hukum Islam pada zaman Sultan Agung sangat hebat, sampai ia menyebut dirinnya sebagai "Abdul Rahman Sayyidin Panatagama Khalifatullah", Demikian juga di Banten Pada masa kekuasaan Sultan Ageng Tirtayasa hukum adat dan hukum agama tidak ada bedanya. Juga di sulawesi. Kenyataan semacam ini diakui oleh Belanda ketika datang ke Indonesia. Dibawah ini akan di kemukakan teori-teori berlakunya hukum Islam di Indonesia.

Pertama, teori Receptio in Complexu, teori ini dimunculkan oleh Van den Berg, berdasarkan kenyataan bahwa hukum Islam diterima (diresepsi) secara menyeluruh oleh ummat Islam. Teori Receptie mengatakan bahwa hukum yang hukum berlaku bagi orang Islam adalah hukum adat mereka masing-masing. Hukum Islam dapat berlaku apabila telah diresepsi oleh hukum adat. Jadi hukum adatlah yang menentukan ada tidaknya hukum Islam. Ketiga, Teori Receptie Exit Atau Receptie a Contrario, Teori Receptie Exit atau Receptie a Contrario adalah teori yang mengatakan bahwa hukum adat baru berlaku kalau tidak bertentangan dengan hukum islam.yaitu hukum islam dapat dilaksanakan ,apabila diterima (diresepsi) hukum adat, maka sekarang hukum adat yang tidak sejalan dengan hukum islam harus dikeluarkan, dilawan atau di tolak. ${ }^{39}$

Perkembangan legalisasi hukum Islam di Indonesia ini memakan waktu yang sangat lama, dan ternyata setelah dirunut masih ada keterkaitan dengan isu-isu modernisasi hukum di dunia Islam terutama pengarut dari munculnya reformasi hukum di Turki dan Mesir, juga melahirkan hukum keluarga Islam modern, termasuk Indonesia sendiri agak terlambat dalam melakukan kodifikasi dan modernisasi hukum. Oleh karena itu, tema ini sangat penting untuk dikaji tentang sejarah modernsasi hukum terutama dalam UU No. 1 Tahun 1974, Kompilasi Hukum Islam (KHI), Kompilasi Hukum Ekonomi Syariah (KHES) sebagai bentuk comparative study of law di dunia Islam khsusnya di Indonesia menuju hukum modern dan hukum yang mampu menghadapi tantangan modernitas. Teori sociological jurisprudence inilah memeberikan pengaruh besar dalam dinamika modernisasi hukum Islam Modern.

Dalam teori Sosiologi Hukum, "law is clothes the living body of society" merupakan pernyataan A. P. Craabree LLB bahwa hukum itu harus mengikuti sesuai kebutuhan masyarakat yang hidup (living law) dengan berdasarkan kemaslahatan dan keadilan. ${ }^{40}$ Dari sinilah dapat dilihat penting teori sosiologi hukum sebagai respons terhadap fenomena masyarakat. ${ }^{41}$ Di sinilah pentingnya modernisasi hukum dalam pengembangan masa depan hukum Islam yang lebih dinamis sebagaimana yang dibangun oleh mazhab sociological jurisprudence ini.

Seiring dengan itu, sistem hukum yang berlaku di dunia Islam dapat dibagi menjadi tiga sistem: Pertama, sistem yang masih memberlakukan syari'ah (devine law) sebagai hukum asasi (pokok) dan

39 Anderson, Hukum Islam Di Dunia Modern.

40 Dadan Muttaqien, Peradilan Agama Dan Kompilasi Hukum Islam Dalam Tata Hukum Indonesia, ed. Dadan Muttaqien (Yogyakarta: UII Press, 1999), 80.

${ }^{41}$ A. Malthuf Siroj, Pembaruan Hukum Islam Di Indonesia Telaah Kompilasi Hukum Islam, ed. Muhammad Al-Fayyadl (Yogyakarta: Pustaka Ilmu, 2012), iii-iv. 
berusaha untuk menerapkanya dalam segala aspek hubungan kemanusiaan secara utuh. Biasanya sistem ini mempunyai kecenderungan bahwa hukum Islam dipahami secara tektual-literal. Semisal dalam hukum keluarga yang diberlakukan adalah otoritas talak hanya dimiliki oleh laki-laki, pemberlakuan poligami dan lain-lain. Diantara negara yang hingga kini mempertahankan model semacam ini adalah Arab Saudi dan wilayah utara Nigeria termasuk di Indonesia yang tercover dalan KHI tentang poligami. Kedua, sistem yang meninggalkan syari'ah dan menggantikanya dengan hukum sekuler. Negara muslim yang setidak-tidaknya secara resmi, telah sama sekali berubah menjadi sekuler adalah Turki yang sangat berbeda atau bertolak belakang dengan Arab saudi. Pada tahun 1926 hukum Swiss ditetapkan sebagai pengganti hukum Islam. Modernisasi hukum ini sangat berbedi dengan hukum Islam seperti monogami diterapkan sebagai pengganti poligami dan biasanya memberlakukan hukum sesuai HAM, CEDAW, dan keadilan. ${ }^{42}$ Ketiga, sistem yang mencoba mengambil jalan moderat diantara dua sistem hukum yang ekstrim nyakni menerapkan hukum Islam secara penuh dan sistem yang sama sekali menolak hukum Islam. Contoh negara yang berusaha mengkompromikan kedua sistem tersebut adalah antara lain Mesir, Sudan, dan Yordania. Akan tetapi khusus dalam hukum keluarga yang diterapkan seringkali porsi yang banyak diberikan adalah hukum Islam sebagaimana dipahami oleh kelompok pertama.

Ketiga sisitem hukum Islam di dunia Muslim diatas mengindikasikan bahwa perbedaan sistem dan bentuk modernisasi hukum bukan hanya disebabkan oleh sistem politik yang dianut, melainkan juga oleh faktor perbedaan sejarah, sosiologi, dan kultur masing-masing negara. Termasuk Indonesia yang melahirkan produk hukum Kompilasi Hukum Islam kemudian muncul KHI tandingan (baca: CLD-KHI) adalah bagian dari pengaruh sistem hukum yang ada di negara-negara Muslim. KHI yang menganut sistem pertama, dan Couter Legal Draft KHI cenderung mengacu pada sekularisasi atau modernisasi hukum di Indonesia.

Secara historis, hukum keluarga Islam mencuat kepermukaan bermula dari diakuinya Peradilan Agama (PA) secara resmi sebagai salah satu pelaksana "judicial power" dalam negara hukum RI lewat pasal 10 UU. No.14 th. 1970. Lebih lanjut, kedudukan, kewenangan atau yurisdiksi dan organisatorisnya telah diatur dan dijabarkan dalam UU. No. 7 tahun 1989 jo UU No 3 tahun 2006, yang mempunyai kewenangan mengadili perkara tertentu seperti perkawinan, warits, wasiat, hibah, wakaf, infaq, shadaqah, zakat, dan ekonomi syari'ah, bagi pendudukyang beragama Islam. Akan tetapi, keberadaan PA tidak disertai dengan perangkat atau sarana hukum positif yang pasti dan berlaku secara unifikasi sebagai rujukan. Walupun sebenarnya sebagian hukum materiil yang menjadi yurisdiksi PA, sudah dikodifikasi UU. No. 1 Tahun 1974 dan PP. No. 9 Tahun 1975; mengandung aturan hukum materiil bidang hukum perkawinan. Akan tetapi pada dasarnya hal-hal yang diatur didalamnya baru merupakan pokok-pokok. Belum secara menyeluruh terjabar ketentuan-ketentuan hukum secara terperinci atau banyak hal yang urgen belum disentuh. Akibatnya, para Hakim lari merujuk kepada doktrin ilmu fikih. Terjadilah suasana praktek PA yang menonjolkan dan mempertarungkan kitab fikih dan pendapat Imam mazhab. Pada saat itu, berakibat pada perbedaan putusan hukum antar PA tentang persoalan yang sama. Banar-benar berlaku ungkapan different judge different sentence, lain hakim lain pendapat dan putusanya. ${ }^{43}$

Dari realitas di atas, pemerintah kemudian berinisiatif melengkapi PA dengan prasarana hukum yang unifikatif lewat jalan pintas berupa Kompilasi Hukum Islam (KHI) dengan Pengukuhan

\footnotetext{
${ }_{42}$ Amir \& Yusdani Mu'allim, Konfigurasi Pemikiran Hukum Islam (Yogyakarta: UII Press, 1999), 7.

43 Cik Hasan Bisri, Kompilasi Hukum Islam Dan Peradilan Agama Dalam Sistem Hukum Nasional (Jakarta: Logos, 1999).
} 
formilnya dalam bentuk Inpres No. 1 Tahun 1991, kemudian diikuti dengan berkembangnya hukum positif Islam lainnya seperti UU Wakaf, UU No. 1 tentang Perkawinan dan seterusnya. Dari sinilah pendekatan mazhab sociological jurisprudence sangat penting untuk memadukan penbacaan secara seimbang antara min al-wāqi' ilā al- naṣṣ (sosiologi hukum) dan min al-nașṣ ilā al-wāqi' (sociological jurisprudence) sesuai dengan dengan situasi dan kondisi masyarakat, sehingga modernisasi hukum Islam ini bisa berjalan dengan baik.

\section{Penutup}

Sejarah perkembangan hukum Islam yang termuat dalam aturan sistem hukum di atas, masih mengandung banyak kekurangan dan kelemahan atau banyak persoalan krusial yang muncul sebagai konsekuensi logis dari dinamika kehidupan di masyarakat Muslim. Akan tetapi menjadi contribution to knowlede pentingnya pendekatan madzhab sociological jurisprudence (min al-nașș ilā al-wāqi') sebagai pembacaan secara seimbang antara min al-wāqi' ilā al-nașș (sosiologi hukum) sesuai dengan dengan situasi dan kondisi masyarakat, sehingga modernisasi hukum Islam ini bisa berjalan dengan baik dan lebih dinamis sesuai perkembangan hukum yang hidup di masyarakat (living law).

Kajian modernsasi hukum modern ini sebagai bentuk comparative study of Islamic law di dunia Islam termasuk pengaruhnya di Indonesia menuju hukum modern dan hukum yang mampu menghadapi tantangan modernitas. Mazhab sociological jurisprudence inilah memeberikan pengaruh besar dalam dinamika modernisasi hukum Islam Modern di dunia Muslim termasuk Indonesia. Secara implentatif, mazhab sociological jurisprudence dalam era moderniasi hukum terutama isu-isu hukum perkawinan, seperti fenomena kawin beda agama, problematikan nikah sirri, persoalan poligami, dan persoalan kesetaraan laki-laki dan perempuan, masih perlu dilakukan upaya modernisasi hukum, karena persoalan-persoalan tersebut terus berkembang dan posisi hukum harus selalu dinamis dalam menanggapi problem sosiologis yang selalu hidup di masyarakat (living law). Hal inilah yang kemudian menimbulkan minimnya renspon masyarakat untuk mentaati atau memakai hukum Islam secara proporsional.

Oleh karena itu, hukum Islam perlu perbaikan, kontekstualisasi atau menambah poin-poin tertentu untuk disesuaikan dengan tuntutan perkembangan masyarakat, sehingga di sinilah bentuk dinamika hukum Islam semakin berkembang ke arah modernisasi hukum bahkan reformasi hukum yang lebih baik. Paling tidak langkah ini menjadi alternatif modernisasi hukum Islam di Indonesia melalui pembacaan madzhab sociological jurisprudence, menuju hukum yang lebih aplicable dan sesuai kebutuhan masyarakat.

\section{DAFTAR PUSTAKA}

Anderson, J. N. D. Hukum Islam Di Dunia Modern. Surabaya: Amar Press, 1991.

--- Law Reform in the Muslim Word. London: Athlon Press, 1976.

Bisri, Cik Hasan. Kompilasi Hukum Islam Dan Peradilan Agama Dalam Sistem Hukum Nasional. Jakarta: Logos, 1999.

Buang, Ahmad Hidayat. “Reformasi Undang-Undang Keluarga Islam.” Syari'ah 5, no. 1 (1997).

Fuady, Munir. Teori-Teori Dalam Sosiologi Hukum. Jakarta: Predana Media Group, 2011. 
Gibb, H. A. R. Modern Trends In Islam. Chicago: Chicago University Press, 1994.

Gilissen, Emiritus John \& Emiritus Frits Gorle. Sejarah Hukum Suatu Pengantar. Edited by Fredi Tengker. Jakarta: Refika Aditama, 2009.

Mahmassani, Sobhi. Filsafat Hukum Dalam Islam. Edited by Ahmad Sudjono. Bandung: PT. Maarif, 1981. Mahmood, Tahir. Family Law Reform in the Muslim World. New Delhi: Pvt. Ltd, 1972.

Mu’allim, Amir \& Yusdani. Konfigurasi Pemikiran Hukum Islam. Yogyakarta: UII Press, 1999.

Muttaqien, Dadan. Peradilan Agama Dan Kompilasi Hukum Islam Dalam Tata Hukum Indonesia. Edited by Dadan Muttaqien. Yogyakarta: UII Press, 1999.

Nasution, Khoiruddin. Hukum Perdata (Keluarga) Islam Indonesia: Dan Perbandingan Hukum Perkawinan Di Dunia Muslim. Yogyakarta: Tazzafa \& Academia, 2009.

--- Status Wanita Di Asia Tenggara: Studi Tentang Perundangundangan Perkawinan Muslim Kontemporer Di Indonesia Dan Malaysia. Jakarta: INIS Press, 2002.

Otje, Salam \& Anton F. Susanto. Beberapa Aspek Sosiologi Hukum. Bandung: Alumni Press, 2004.

Rahardjo, Satjipto. Ilmu Hukum. Bandung: Citra Adtya Bakti, 1991.

Rasjidi dan Ira Rasjidi. Dasar-Dasar Filsafat Dan Teori Hukum. Bandung: PT.Citra Aditya Bakti, 2001.

Schacht. The Law, Yunity and Variety in Moslem Civilization. Chicago: University of Chicago Press, 1955.

Sidarta, B. Arief. Filsafat Hukum Mazhab Dan Refleksinya. Bandung: Remaja Rosda Karya, 1994.

Siroj, A. MAlthuf. Pembaruan Hukum Islam Di Indonesia Telaah Kompilasi Hukum Islam. Edited by Muhammad Al-Fayyadl. Yogyakarta: Pustaka Ilmu, 2012.

Soerjono Soekanto \& Purnadi Purbacaraka. Perihal Kaidah Hukum. Bandung: Citra Aditya Bakti, 1989.

Suda, Zdenek. Teori, Riset, Dan Realitas. Edited by Hartono Hadikusumo. Yogyakarta: Tiara Wacana, 1998.

Summa, Muhammad Amin. Hukum Keluarga Islam Di Dunia Islam. Jakarta: RajaGrasindo, 2004.

Tebba, Sudirman. Sosiologi Hukum Islam. Yogyakarta: UII Press, 2003.

Zubaida, Sami. Law and Power in The Islamic World. London: MPG Book, 2003. 